\title{
Alkaline Ceramidase 2
}

National Cancer Institute

\section{Source}

National Cancer Institute. Alkaline Ceramidase 2. NCI Thesaurus. Code C103895.

Alkaline ceramidase $2(275 \mathrm{aa}, \sim 31 \mathrm{kDa})$ is encoded by the human ACER2 gene. This protein plays a role in ceramide metabolism and sphingosine synthesis. 